\title{
Translation, cultural adaptation and validation of the Diabetes Attitudes Scale - third version into Brazilian Portuguese ${ }^{1}$
}

\author{
Gisele de Lacerda Chaves Vieira ${ }^{2}$ \\ Adriana Silvino Pagano ${ }^{3}$ \\ Ilka Afonso Reis ${ }^{4}$ \\ Júlia Santos Nunes Rodrigues ${ }^{5}$ \\ Heloísa de Carvalho Torres ${ }^{6}$
}

\begin{abstract}
Objective: to perform the translation, adaptation and validation of the Diabetes Attitudes Scale - third version instrument into Brazilian Portuguese. Methods: methodological study carried out in six stages: initial translation, synthesis of the initial translation, back-translation, evaluation of the translated version by the Committee of Judges (27 Linguists and 29 health professionals), pre-test and validation. The pre-test and validation (test-retest) steps included 22 and 120 health professionals, respectively. The Content Validity Index, the analyses of internal consistency and reproducibility were performed using the $\mathrm{R}$ statistical program. Results: in the content validation, the instrument presented good acceptance among the Judges with a mean Content Validity Index of 0.94. The scale presented acceptable internal consistency (Cronbach's alpha $=0.60$ ), while the correlation of the total score at the test and retest moments was considered high (Polychoric Correlation Coefficient $=0.86$ ). The Intra-class Correlation Coefficient, for the total score, presented a value of 0.65. Conclusion: the Brazilian version of the instrument (Escala de Atitudes dos Profissionais em relação ao Diabetes Mellitus) was considered valid and reliable for application by health professionals in Brazil.
\end{abstract}

Descriptors: Translating; Surveys and Questionnaires; Diabetes Mellitus; Health Knowledge, Attitudes, Practice; Validation Studies; Reproducibility of Results.

\footnotetext{
${ }_{1}^{1}$ Paper extracted from Doctoral Dissertation "Tradução, adaptação cultural e validação do instrumento Diabetes Attitudes Scale", presented to Escola de Enfermagem, Universidade Federal de Minas Gerais, Belo Horizonte, MG, Brazil.

${ }^{2}$ Doctoral student, Escola de Enfermagem, Universidade Federal de Minas Gerais, Belo Horizonte, MG, Brazil.

${ }^{3} \mathrm{PhD}$, Full Professor, Faculdade de Letras, Universidade Federal de Minas Gerais, Belo Horizonte, MG, Brazil.

${ }^{4} \mathrm{PhD}$, Adjunct Professor, Instituto de Ciências Exatas, Universidade Federal de Minas Gerais, Belo Horizonte, MG, Brazil.

${ }^{5}$ Undergraduate student in Language and Literature, Faculdade de Letras, Universidade Federal de Minas Gerais, Belo Horizonte, MG, Brazil.

${ }^{6} \mathrm{PhD}$, Associate Professor, Escola de Enfermagem, Universidade Federal de Minas Gerais, Belo Horizonte, MG, Brazil.
}

\section{How to cite this article}

Vieira GLC, Pagano AS, Reis IA, Rodrigues JSN, Torres HC. Translation, cultural adaptation and validation of the Diabetes Attitudes Scale - third version into Brazilian Portuguese. Rev. Latino-Am. Enfermagem. 2017;25:e2875. [Access

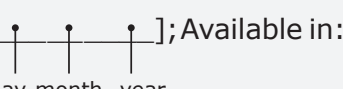

day month year DOI: http://dx.doi.org/10.1590/1518-8345.1404.2875. 


\section{Introduction}

Health professionals can significantly contribute so that the person living with diabetes can achieve the objectives related to glycemic control(1). However, it has been observed that the practices of these professionals are still eminently prescriptive, being influenced, in the majority of cases, by the attitudes that they have in relation to the diabetes condition ${ }^{(2-3)}$.

Studies have identified the greatest trend of health professionals to be the adoption of a paternalistic attitude regarding decisions related to the treatment, with the justification that they know what is best for the person with the condition of diabetes ${ }^{(3-4)}$. In contrast, studies have shown the importance of the participation and empowerment of people living with this condition for achieving adequate outcomes and preventing complications related to diabetes ${ }^{(4-5)}$.

As the attitudes of the professionals determine the behavior they adopt ${ }^{(6-8)}$ and how they interact with people who have diabetes, causing repercussions in the treatment outcomes, it is necessary to identify the attitudes of these professionals when faced with this condition ${ }^{(9)}$. By identifying these attitudes, it is possible to establish educational strategies that contribute to a professional practice that considers the integrality of the care and the life context of the person with diabetes ${ }^{(7-9)}$. Therefore, valid and reliable instruments need to be used to measure the attitudes of these professionals, which also allow the results of research conducted in different countries to be compared.

Among the instruments available in the literature ${ }^{(9-10)}$, the Diabetes Attitudes Scale - third version (DAS-3) is the instrument which has the broadest spectrum of dimensions to assess the attitudes of health professionals in relation to diabetes mellitus. The construction of this instrument was guided by the Theory of Planned Action( ${ }^{(9)}$. According to this theory, the intention of a person to perform certain behavior can be measured through the attitudes. The attitudes, in turn, are measured indirectly through the beliefs verbalized by the people, being able to strongly predict the behaviors that they $\operatorname{adopt}^{(7)}$.

The DAS-3 consists of 33 questions divided in five related subscales: 1 ) need for special training to conduct educational interventions; 2) seriousness of Type 2 Diabetes; 3 ) value of strict glucose control for diabetes care; 4) psychosocial impact of diabetes on the lives of people and 5) autonomy of the person with diabetes ${ }^{(9)}$. It should be noted that the DAS-3 went through an evaluation process with 1,430 health professionals, proving to be valid and reliable, and has been translated and adapted to other countries, with the ability to maintain the original characteristics to measure the construct analyzed(9,11-12).

In order to provide an instrument for use in the Brazilian context, this study aimed to carry out the translation, adaptation and validation of the Diabetes Attitudes Scale - third version (DAS-3).

\section{Method}

This methodological study followed the recommendations established in the literature ${ }^{(13)}$. In the analysis of the conceptual equivalence and items, concepts related to diabetes and to the attitudes construct were explored in order to verify whether the dimensions of the instrument are relevant to the Brazilian cultural context. Considering the viability and relevance of using DAS-3 in Brazil, the following steps were performed.

The translation was carried out independently by two translators, generating the $\mathrm{T} 1$ and $\mathrm{T} 2$ versions in Brazilian Portuguese. The translated versions were then compared by the same two translators and a third translator, which gave rise to a consensus version (T1-2). Next the instrument was backtranslated to its original language, independently, by two other translators, in order to verify the concordance between the original version and the consensus version $(\mathrm{T} 1-2)^{(13)}$.

After these steps, 30 health professionals and 30 from the field of Applied Linguistics were invited to participate as the Committee of Judges ${ }^{(13)}$. This was a convenience sample. The invitation was sent by e-mail and a link provided for access to the instrument previously uploaded to the web e-Surv platform. The judges were divided into three groups so that each group evaluated 11 statements, since the review of all 33 questions would take longer than 45 minutes. All the participants evaluated the instructions of the instrument and response options so that there was no impairment in the understanding and evaluation of the translated version. The aim was to evaluate the semantic, idiomatic, conceptual and experiential equivalences.

When comparing the original and the translated version, the judges evaluated the instrument according 
to the need for retranslation ( 1 = requires complete retranslation; 2 = requires partial retranslation with many changes; 3 = requires partial retranslation with a few changes; $4=$ does not require retranslation) and the relevance of the reduction of the response options (from five options to four options).

After obtaining the responses of the judges, the Content Validity Index (CVI) was calculated, defined by the sum of the relative frequencies of the " 3 " and " 4 " responses ${ }^{(14)}$. The assumption that the higher the CVI, the lower the number of changes needed to improve the text was considered.

A total of 22 health professionals that provided care to people with diabetes mellitus participated in the pre-test stage. In this stage, the questionnaire was sent electronically, and the link to access the instrument was provided. The professionals were asked to respond to the 33 statements of the instrument, to evaluate each statement for ease of understanding and clarity of the information and to present suggestions for improvement of the text ${ }^{(13-14)}$.

Finally, in order to verify its validity and reliability, the instrument was applied, through the web e-Surv platform, with health professionals on two occasions with an interval of 15 days between the test and retest ${ }^{(14)}$.

To calculate the sample size, a psychometric property was chosen that involves both the moment of the test and of the retest, the temporal reproducibility, and an alternative to its measure, the linear correlation. Thus, a significance level of $5 \%$, test power of $80 \%$, standard deviation equal in the test and retest scores and a correlation coefficient of 0.30 (minimum value to be detected in the evaluation of reliability) were considered. The minimum sample size required was 82 professionals. When considering a $20 \%$ losses, the final sample size required was 100 health professionals.

The selection of the professionals was performed by convenience from the database of the project entitled "Measurement instruments for educational practices in chronic disease: interdisciplinarity and innovation". Each professional that agreed to take part in the study was asked to indicate other professionals that worked with people who have diabetes. The application of the instrument was conducted in March and April 2016.

The descriptive analysis of the categorical variables was performed by calculating the absolute and relative frequencies and, for the quantitative variables, the means, standard deviation, and percentiles were calculated. The evaluation of the internal consistency was made from the calculation of Cronbach's alpha(15).

In the analysis of the reliability of the instrument, the Polychoric Correlation Coefficient was used, as the response scale is of the categorical ordinal type ${ }^{(16)}$. As with the Pearson's linear correlation coefficient, the polychoric correlation coefficient can have values between -1 and 1 . The stronger correlations relate to coefficient values closer to -1 (negative correlations) or 1 (positive correlations). Polychoric correlation coefficient values near zero indicate weak or no linear correlations. The percentage of concordance between the responses in the test-retest was calculated to support the decision regarding the temporal stability of the instrument.

The Intra-class Correlation Coefficient (ICC) was also used as a measure of concordance between the total score obtained in the two applications of the instrument, while the Wilcoxon test was used to verify whether there was a statistical difference between the median score of the first and second application of the instrument ${ }^{(11)}$. Data analysis was carried out using the $\mathrm{R}^{+}$statistical program. The significance level considered for the statistical tests was $5 \%$.

The study was approved by the Research Ethics Committee of the Federal University of Minas Gerais (Authorization No. 1.072.984). The consent form was made available electronically on the first page of the questionnaire, where the professionals recorded their agreement to participate in the study.

\section{Results}

From the 60 invitations sent to the sample of professionals selected to participate in the Committee of Judges, 56 completed questionnaires were obtained, 29 completed by the health professionals $(51.8 \%)$ and 27 by the linguists $(48.2 \%)$. A total of $3.7 \%$ of the judges reported Lato sensu postgraduate level education and $80.3 \%$ reported having performed a Stricto sensu post-graduate course.

In general, the instrument presented high levels of CVI, resulting in a mean CVI of 0.94 , with a standard deviation of 0.09 . Statements 16 and 27, however, presented the lowest CVI values, indicating the need for further changes, as shown in Table 1.

The reduction of response options to four alternatives was evaluated as relevant by the judges and by the health professionals. The reasons given were: ease of choice and understanding of the 
answer choices among people who would respond to the instrument; no significant difference within the Brazilian cultural context between the options, "disagree" and "totally disagree".

In order to preserve the comparison between the scores obtained with the original instrument and the instrument translated and adapted in Brazil, it was decided to maintain the score of response options with the range between 1 and 5 points. Thus, the following points were awarded to the statements with scores in direct order: disagree - 1 point, no opinion - 3 points, partially agree - 4 points, agree - 5 points. Regarding the statements that have reversed scores $(2,3,7,11,13,15,16,23,26$ and $28)$, the points were distributed as follows: agree - 1 point, partially agree - 2 points, no opinion - 3 points and disagree - 5 points. It is important to note that the "no opinion" option is scored the same in direct and reverse order.

The main changes made in the translated version after the suggestions given by the judges and in the pretest phase were: (1) replacing the term "patient", "user" and "diabetic" with "person with diabetes"; (2) inclusion of physiotherapy, pharmacy, physical education and psychology professionals; (3) changing the expression "self-care plan" to "care plan" and (4) replacing the word "disease" with "chronic condition". After these steps, the final version of the Escala de Atitudes dos Profissionais em relação ao Diabetes Mellitus (EAP-DM) was obtained, as presented in Figure 1.

Table 1 - Absolute and relative frequencies of the responses of the Committee of Judges in the evaluation of the instrument items and content validity index. Belo Horizonte, MG, Brazil, 2015

\begin{tabular}{|c|c|c|c|c|c|}
\hline \multirow[t]{2}{*}{ Item } & $\begin{array}{l}\text { Requires complete } \\
\text { retranslation }\end{array}$ & $\begin{array}{l}\text { Requires partial retranslation } \\
\text { with many changes }\end{array}$ & $\begin{array}{l}\text { Requires partial retranslation } \\
\text { with a few changes }\end{array}$ & $\begin{array}{l}\text { Does not require } \\
\text { retranslation }\end{array}$ & $\mathrm{CVI}^{*}$ \\
\hline & \multicolumn{4}{|c|}{$\mathbf{N}(\%)^{\dagger}$} & \\
\hline Instructions & 0 & $5(8.9)$ & $20(35.7)$ & $31(55.4)$ & 0.91 \\
\hline Response options & $1(1.8)$ & $1(1.8)$ & 19 (33.9) & $35(62.5)$ & 0.96 \\
\hline 1 & 0 & $2(11.1)$ & $9(50.0)$ & $7(38.9)$ & 0.89 \\
\hline 2 & 0 & 0 & $8(44.4)$ & $10(55.6)$ & 1,00 \\
\hline 3 & 0 & 0 & $8(44.4)$ & $10(55.6)$ & 1,00 \\
\hline 4 & 0 & 0 & $3(16.7)$ & $15(88.3)$ & 1.00 \\
\hline 5 & 0 & 0 & $6(33.3)$ & $12(66.7)$ & 1.00 \\
\hline 6 & 0 & 0 & $6(33.3)$ & $12(66.7)$ & 1.00 \\
\hline 7 & 0 & 0 & $1(5.6)$ & $17(94.4)$ & 1.00 \\
\hline 8 & 0 & 0 & $1(5.6)$ & $17(94.4)$ & 1.00 \\
\hline 9 & 0 & $1(5.6)$ & $4(22.2)$ & $13(72.2)$ & 0.94 \\
\hline 10 & 0 & 0 & $9(50.0)$ & $9(50.0)$ & 1.00 \\
\hline 11 & 0 & 0 & $11(61.1)$ & $7(38.9)$ & 1.00 \\
\hline 12 & 0 & 0 & $8(40.0)$ & $12(60.0)$ & 1.00 \\
\hline 13 & 0 & $3(15.0)$ & $5(25.0)$ & $12(60.0)$ & 0.85 \\
\hline 14 & $1(5.0)$ & $1(5.0)$ & $11(55.0)$ & $7(35.0)$ & 0.90 \\
\hline 15 & 0 & $2(10.0)$ & $9(45.0)$ & $9(45.0)$ & 0.90 \\
\hline 16 & $7(35.0)$ & $2(10.0)$ & $4(20.0)$ & $7(35.0)$ & 0.55 \\
\hline 17 & 0 & 0 & $7(35.0)$ & $13(65.0)$ & 1.00 \\
\hline 18 & $1(5.0)$ & 0 & $5(25.0)$ & $14(70.0)$ & 0.95 \\
\hline 19 & 0 & 0 & $7(35.0)$ & $13(65.0)$ & 1.00 \\
\hline 20 & 0 & $1(5.0)$ & $3(15.0)$ & $16(80.0)$ & 0.95 \\
\hline 21 & 0 & 0 & 0 & $20(100.0)$ & 1.00 \\
\hline 22 & 0 & $1(5.0)$ & $4(20.0)$ & $15(75.0)$ & 0.95 \\
\hline 23 & $1(5.0)$ & $3(15.0)$ & $4(20.0)$ & $12(60.0)$ & 0.80 \\
\hline 24 & 0 & $3(16.7)$ & $11(61.1)$ & $4(22.2)$ & 0.83 \\
\hline 25 & 0 & 0 & $3(16.7)$ & $15(83.3)$ & 1.00 \\
\hline 26 & 0 & 0 & $4(22.2)$ & $14(77.8)$ & 1.00 \\
\hline 27 & $1(5.6)$ & $3(16.7)$ & $10(55.6)$ & $4(22.2)$ & 0.78 \\
\hline 28 & 0 & 0 & $7(38.9)$ & $11(61.1)$ & 1.00 \\
\hline 29 & 0 & $2(11.1)$ & $7(38.9)$ & $9(50.0)$ & 0.89 \\
\hline 30 & 0 & 0 & $12(66.7)$ & $6(33.3)$ & 1.00 \\
\hline 31 & 0 & $1(5.6)$ & $9(50.0)$ & $8(44.4)$ & 0.94 \\
\hline 32 & 0 & 0 & $6(33.3)$ & $12(66.7)$ & 1.00 \\
\hline 33 & 0 & 0 & $1(5.6)$ & 17 (94.4) & 1.00 \\
\hline Mean CVI (SD) & & & $0.94(0.09)$ & & \\
\hline
\end{tabular}

*CVI - content validity index; tThe relative frequencies sum to $100 \%$ within the lines and absolute frequencies correspond to the number of evaluator Judges for each group of statements of the instrument, with 18 of them assessing questions 1 to $11 ; 20$ judges assessing questions 12 to 23 ; and 18 judges assessing questions 24 to 33 . All the judges reviewed the instructions and instrument response options. 


\begin{tabular}{|c|c|}
\hline Original version & Final version \\
\hline $\begin{array}{l}\text { Title } \\
\text { Diabetes Attitudes Scale - third version }\end{array}$ & $\begin{array}{l}\text { Title } \\
\text { Escala de atitudes dos profissionais em relação ao Diabetes Mellitus } \\
\text { (EAP-DM) }\end{array}$ \\
\hline $\begin{array}{l}\text { Instructions } \\
\text { Below are some statements about diabetes. } \\
\text { Each numbered statement finishes the sentence "In general, I believe } \\
\text { that..." } \\
\text { You may believe that a statement is true for one person but not for } \\
\text { another person or may be true one time but not be true another time. } \\
\text { Place a check mark in the box below the word or phrase that is closest } \\
\text { to your opinion about each statement. Note: The term "health care } \\
\text { professionals" in this survey refers to doctors, nurses, and dietitians. }\end{array}$ & $\begin{array}{l}\text { Instructions } \\
\text { As afirmativas a seguir, referem-se ao diabetes e complementam a } \\
\text { frase "Em geral, em acredito que..." Ao ler cada uma das afirmativas, } \\
\text { MARQUE a resposta que, na sua opinião, seja verdadeira para a maioria } \\
\text { das situações ou que se aplique para a maioria das pessoas. } \\
\text { Observação: Nesta pesquisa, o termo "profissionais da saúde" refere-se } \\
\text { a médicos, enfermeiros, nutricionistas, fisioterapeutas, farmacêuticos, } \\
\text { psicólogos e educador físico. }\end{array}$ \\
\hline $\begin{array}{l}\text { Response options } \\
\text { Mark the answer that you believe is true most of the time or is true for } \\
\text { most people. } \\
\text { () Strongly Agree } \\
\text { () Agree } \\
\text { () Neutral } \\
\text { () Disagree } \\
\text { ( ) Strongly Disagree }\end{array}$ & $\begin{array}{l}\text { Response options } \\
\text { Marque a opção que mais representa sua opinião sobre cada afirmativa. } \\
\text { Concordo } \\
\text { Concordo em parte } \\
\text { Não tenho opinião } \\
\text { Discordo }\end{array}$ \\
\hline $\begin{array}{l}\text { 1...health care professionals who treat people with diabetes should be } \\
\text { trained to communicate well with their patients. }\end{array}$ & $\begin{array}{l}\text { 1... os profissionais da saúde deveriam ser capacitados para ter uma boa } \\
\text { comunicação com as pessoas que têm diabetes. }\end{array}$ \\
\hline $\begin{array}{l}\text { 2...people who do not need to take insulin to treat their diabetes have a } \\
\text { pretty mild disease. }\end{array}$ & $\begin{array}{l}\text { 2...as pessoas que não precisam aplicar insulina têm uma forma menos } \\
\text { grave do diabetes. }\end{array}$ \\
\hline $\begin{array}{l}\text { 3...there is not much use in trying to have good blood sugar control } \\
\text { because the complications of diabetes will happen anyway. }\end{array}$ & $\begin{array}{l}\text { 3...não é tão necessário controlar a glicemia, porque as complicações } \\
\text { que acontecem por causa do diabetes ocorrerão de qualquer maneira. }\end{array}$ \\
\hline 4... diabetes affects almost every part of a diabetic person's life. & $\begin{array}{l}\text { 4... o diabetes afeta praticamente todos os aspectos da vida de quem } \\
\text { tem esta condição. }\end{array}$ \\
\hline $\begin{array}{l}5 . . . \text { the important decisions regarding daily diabetes care should be made } \\
\text { by the person with diabetes. }\end{array}$ & $\begin{array}{l}\text { 5....as decisões importantes relativas ao autocuidado diário devem ser } \\
\text { tomadas pela própria pessoa que tem o diabetes. }\end{array}$ \\
\hline $\begin{array}{l}\text { 6...health care professionals should be taught how daily diabetes care } \\
\text { affects patients' lives. }\end{array}$ & $\begin{array}{l}6 \ldots \text { os profissionais da saúde devem ser instruídos sobre como a rotina } \\
\text { diária do autocuidado afeta a vida da pessoa que tem diabetes. }\end{array}$ \\
\hline 7...older people with type 2 diabetes do not usually get complications. & $\begin{array}{l}\text { 7...geralmente, os idosos com diabetes tipo } 2 \text { não desenvolvem } \\
\text { complicações relacionadas à esta condição crônica. }\end{array}$ \\
\hline $\begin{array}{l}8 . . . \text { keeping the blood sugar close to normal can help to prevent the } \\
\text { complications of diabetes. }\end{array}$ & $\begin{array}{l}\text { 8...manter a glicemia próxima do normal ajuda a prevenir complicações } \\
\text { causadas pelo diabetes. }\end{array}$ \\
\hline $\begin{array}{l}\text { 9...health care professionals should help patients make informed choices } \\
\text { about their care plans. }\end{array}$ & $\begin{array}{l}\text { 9... os profissionais da saúde devem ajudar as pessoas que têm diabetes } \\
\text { a tomarem decisões conscientes sobre o seu plano de cuidados. }\end{array}$ \\
\hline $\begin{array}{l}\text { 10... it is important for the nurses and dietitians who teach people with } \\
\text { diabetes to learn counseling skills. }\end{array}$ & $\begin{array}{l}\text { 10...é importante que os profissionais da saúde que ensinam pessoas } \\
\text { que têm diabetes aprendam estratégias de aconselhamento. }\end{array}$ \\
\hline $\begin{array}{l}11 \ldots \text { people whose diabetes is treated by just a diet do not have to worry } \\
\text { about getting many long-term complications. }\end{array}$ & $\begin{array}{l}\text { 11...as pessoas que controlam o diabetes apenas com a alimentação não } \\
\text { precisam se preocupar com complicações a longo prazo. }\end{array}$ \\
\hline $\begin{array}{l}\text { 12... almost everyone with diabetes should do whatever it takes to keep } \\
\text { their blood sugar close to normal. }\end{array}$ & $\begin{array}{l}\text { 12... todas as pessoas que têm diabetes devem fazer o máximo possível } \\
\text { para manter a glicemia próxima do normal. }\end{array}$ \\
\hline 13...the emotional effects of diabetes are pretty small. & 13... os efeitos emocionais ocasionados pelo diabetes são poucos. \\
\hline $\begin{array}{l}14 \ldots \text { people with diabetes should have the final say in setting their blood } \\
\text { glucose goals. }\end{array}$ & $\begin{array}{l}\text { 14...as pessoas que têm diabetes devem ser as responsáveis pela } \\
\text { decisão de suas metas glicêmicas. }\end{array}$ \\
\hline 15 ...blood sugar testing is not needed for people with type 2 diabetes. & $\begin{array}{l}\text { 15...pessoas que têm diabetes do tipo } 2 \text { não precisam fazer medições de } \\
\text { glicemia. }\end{array}$ \\
\hline $\begin{array}{l}\text { 16...low blood sugar reactions make tight control too risky for most } \\
\text { people. }\end{array}$ & $\begin{array}{l}\text { 16...para a maioria das pessoas, o controle rigoroso da glicemia pode ser } \\
\text { muito arriscado devido ao perigo de elas não reconhecerem os sinais e } \\
\text { sintomas de hipoglicemia. }\end{array}$ \\
\hline $\begin{array}{l}\text { 17... health care professionals should learn how to set goals with patients, } \\
\text { not just tell them what to do. }\end{array}$ & $\begin{array}{l}\text { 17...os profissionais da saúde devem aprender a definir as metas de } \\
\text { comum acordo com as pessoas que têm diabetes e não apenas dizer a } \\
\text { elas o que fazer. }\end{array}$ \\
\hline 18... diabetes is hard because you never get a break from it. & 18...ter diabetes é difícil, porque a pessoa nunca pode parar de se cuidar. \\
\hline $\begin{array}{l}\text { 19....the person with diabetes is the most important member of the } \\
\text { diabetes care team. }\end{array}$ & $\begin{array}{l}\text { 19...a pessoa que tem diabetes é o principal membro entre todos os } \\
\text { envolvidos no plano de cuidados. }\end{array}$ \\
\hline $\begin{array}{l}\text { 20. ...to do a good job, diabetes educators should learn a lot about being } \\
\text { teachers. }\end{array}$ & $\begin{array}{l}\text { 20...para serem bem-sucedidos, os profissionais da saúde envolvidos } \\
\text { com educação em diabetes devem aprender boas práticas de ensino. }\end{array}$ \\
\hline
\end{tabular}




\begin{tabular}{|c|c|}
\hline Original version & Final version \\
\hline 21. ...type 2 diabetes is a very serious disease. & $21 \ldots$ o diabetes tipo 2 é uma condição crônica muito grave. \\
\hline 22. ... having diabetes changes a person's outlook on life. & $\begin{array}{l}22 \ldots . .0 \text { modo como a pessoa enxerga a vida muda quando ela tem } \\
\text { diabetes. }\end{array}$ \\
\hline $\begin{array}{l}\text { 23. ...people who have type } 2 \text { diabetes will probably not get much payoff } \\
\text { from tight control of their blood sugar. }\end{array}$ & $\begin{array}{l}\text { 23... as pessoas com diabetes tipo } 2 \text { provavelmente não terão benefícios } \\
\text { com o controle rigoroso da glicemia. }\end{array}$ \\
\hline $\begin{array}{l}\text { 24. ...people with diabetes should learn a lot about the disease so that } \\
\text { they can be in charge of their own diabetes care. }\end{array}$ & $\begin{array}{l}\text { 24... as pessoas que têm diabetes devem aprender muito sobre esta } \\
\text { condição para se tornarem responsáveis pelo seu plano de cuidados. }\end{array}$ \\
\hline 25. ...type 2 is as serious as type 1 diabetes. & 25... o diabetes tipo 2 é tão grave quanto o diabetes tipo 1. \\
\hline 26. ...tight control is too much work. & $26 \ldots$ o controle rigoroso do diabetes dá muito trabalho. \\
\hline $\begin{array}{l}\text { 27.... what the patient does has more effect on the outcome of diabetes } \\
\text { care than anything a health professional does. }\end{array}$ & $\begin{array}{l}\text { 27... o que a pessoa que tem diabetes faz para cuidar de si possui mais } \\
\text { impacto do que as ações dos profissionais da saúde. }\end{array}$ \\
\hline $\begin{array}{l}\text { 28. ...tight control of blood sugar makes sense only for people with type } \\
1 \text { diabetes. }\end{array}$ & $\begin{array}{l}\text { 28...o controle rigoroso da glicemia só é importante para as pessoas que } \\
\text { têm diabetes tipo } 1 .\end{array}$ \\
\hline 29...it is frustrating for people with diabetes to take care of their disease. & 29... ter que cuidar de si é frustrante para as pessoas que têm diabetes. \\
\hline $\begin{array}{l}30 \ldots \text {...people with diabetes have a right to decide how hard they will work } \\
\text { to control their blood sugar. }\end{array}$ & $\begin{array}{l}\text { 30...as pessoas que têm diabetes podem decidir o quanto que elas estão } \\
\text { dispostas a se esforçar para controlar a glicemia. }\end{array}$ \\
\hline $\begin{array}{l}\text { 31...people who take diabetes pills should be as concerned about their } \\
\text { blood sugar as people who take insulin. }\end{array}$ & $\begin{array}{l}31 \ldots \text { as pessoas que tomam medicamentos orais para controlar o } \\
\text { diabetes devem se preocupar com a glicemia tanto quanto as que } \\
\text { aplicam insulina. }\end{array}$ \\
\hline $\begin{array}{l}\text { 32... people with diabetes have the right not to take good care of their } \\
\text { diabetes. }\end{array}$ & $\begin{array}{l}\text { 32...é direito das pessoas que têm diabetes não querer cuidar de sua } \\
\text { condição crônica. }\end{array}$ \\
\hline 33...support from family and friends is important in dealing with diabetes. & $\begin{array}{l}\text { 33...é importante ter o apoio da família e dos amigos para lidar com o } \\
\text { diabetes. }\end{array}$ \\
\hline
\end{tabular}

Figure 1 - Description of items from the original version of the Diabetes Attitudes Scale - third version and the Brazilian version of the Escala de Atitudes dos Profissionais em relação ao Diabetes Mellitus, Belo Horizonte, MG, Brazil, 2015

A total of 120 health professionals participated in the validation step (test-retest). The characterization of the participants is presented in Table 2.

The overall Cronbach's alpha value for the Escala de Atitudes dos Profissionais em relação ao Diabetes Mellitus was 0.60 , indicating acceptable internal consistency.

Table 2 - Characterization of the professionals that participated in the validation stage of the EAP-DM. Belo Horizonte, MG, Brazil, $2016(n=120)$

\begin{tabular}{lc}
\hline \multicolumn{1}{c}{ Profile of the participants } & $\mathbf{n}(\%)^{*}$ \\
\hline Gender & $103(85.8)$ \\
Female & $17(14.2)$ \\
Male & \\
Area of qualification & $64(53.3)$ \\
Nursing & $35(29.2)$ \\
Medicine & $12(10.0)$ \\
Nutrition & $4(3.3)$ \\
Physiotherapy & $3(2.5)$ \\
Physical Education & $1(0.83)$ \\
Pharmacy & $1(0.83)$ \\
Psychology & \\
Level of practice & $40(33.3)$ \\
Primary & $18(15.0)$ \\
Secondary & $15(12.5)$ \\
Tertiary & $14(11.7)$ \\
Primary and Secondary & $9(7.5)$ \\
Primary and Tertiary &
\end{tabular}

Table 2 - (continuation)

\begin{tabular}{lc}
\hline \multicolumn{1}{c}{ Profile of the participants } & $\mathbf{n}(\%)^{*}$ \\
\hline Level of practice & $15(12.5)$ \\
Secondary and Tertiary & $9(7.5)$ \\
Primary, Secondary and Tertiary & \\
Qualification & $41(34.2)$ \\
Master's degree & $33(27.5)$ \\
Doctoral degree & $32(26.7)$ \\
Specialization & $14(11.7)$ \\
Bachelors degree & \\
Sector of practice & $69(57.5)$ \\
Public & $10(8.3)$ \\
Private & $41(34.2)$ \\
$\quad$ Public and private & \\
Region of the country & $83(69.2)$ \\
Southeast & $15(12.5)$ \\
Central-east & $12(10.0)$ \\
South & $10(8.3)$ \\
Northeast & $8.0(1.0-45.0)$ \\
Years of experience - Median (min-max)
\end{tabular}

$* \mathrm{n}(\%)$ : Absolute and relative frequencies

Table 3 shows the presence of moderate to high correlations between the items at the test and retest moments.

The reliability analysis of the instrument was supported by calculating the Intra-class Correlation Coefficient, which indicated moderate concordance in all subscales and in the general scale, as presented in Table 4. 
Table 3 - Correlation between the responses to the items, between the scores in the subscale and total score in the test and retest and Cronbach's alpha Coefficient (a) for the Escala de Avaliação das Atitudes dos Profissionais em relação ao Diabetes (EAP-DM). Belo Horizonte, MG, Brazil, $2016(n=120)$

\begin{tabular}{|c|c|c|c|}
\hline Subscale and items & $\begin{array}{c}\text { Polychoric Correlation } \\
\text { Coefficient - test and retest }\end{array}$ & $\begin{array}{l}\text { Cronbach's alpha for the } \\
\text { subscales and overall scale }\end{array}$ & $\begin{array}{l}\text { Percentage of concordance between } \\
\text { the responses in the test and retest }\end{array}$ \\
\hline Needs for professional training & 0.987 & 0.57 & \\
\hline Question 1 & 0.813 & & 97.5 \\
\hline Question 6 & -0.894 & & 97.5 \\
\hline Question 10 & 0.768 & & 95.0 \\
\hline Question 17 & 0.731 & & 87.5 \\
\hline Question 20 & 0.778 & & 94.2 \\
\hline Seriousness of Type 2 Diabetes Mellitus & 0.919 & 0.54 & \\
\hline Question 2 & 0.811 & & 72.5 \\
\hline Question 7 & 0.708 & & 91.2 \\
\hline Question 11 & 0.593 & & 91.6 \\
\hline Question 15 & 0.517 & & 89.2 \\
\hline Question 21 & 0.682 & & 67.5 \\
\hline Question 25 & 0.686 & & 74.2 \\
\hline Question 31 & 0.678 & & 83.3 \\
\hline Importance of strict glucose control & 0.900 & 0.55 & \\
\hline Question $3^{\dagger}$ & --- & & 99.2 \\
\hline Question 8 & 0.623 & & 88.3 \\
\hline Question 12 & 0.763 & & 78.3 \\
\hline Question 16 & 0.679 & & 69.2 \\
\hline Question 23 & 0.674 & & 94.2 \\
\hline Question 26 & 0.800 & & 74.2 \\
\hline Question 28 & 0.631 & & 91.6 \\
\hline Psychosocial impact of diabetes & 0.912 & 0.58 & \\
\hline Question 4 & 0.794 & & 82.0 \\
\hline Question 13 & 0.466 & & 92.5 \\
\hline Question 18 & 0.692 & & 70.0 \\
\hline Question 22 & 0.618 & & 56.6 \\
\hline Question 29 & 0.521 & & 65.8 \\
\hline Question $33^{\dagger}$ & --- & & 99.2 \\
\hline Importance of autonomy & 0.891 & 0.58 & \\
\hline Question 5 & 0.642 & & 69.2 \\
\hline Question 9 & 0.587 & & 95.8 \\
\hline Question 14 & 0.659 & & 61.6 \\
\hline Question 19 & 0.565 & & 75.8 \\
\hline Question 24 & 0.574 & & 82.5 \\
\hline Question 27 & 0.443 & & 70.0 \\
\hline Question 30 & 0.653 & & 66.6 \\
\hline Question 32 & 0.752 & & 65.8 \\
\hline Overall score & 0.860 & $0.60 *$ & \\
\hline
\end{tabular}

*Overall alpha; ${ }^{+}$The responses to the question do not show variability in at least one of the moments, with the calculation of the correlation coefficient not being possible

Table 4 - Intra-class correlation coefficient for the overall scale and its subscales. Belo Horizonte, MG, Brazil, 2016 $(n=120)$

\begin{tabular}{lc}
\hline \multicolumn{1}{c}{ Overall scale and subscales } & $\begin{array}{c}\text { Intra-class correlation } \\
\text { coefficient } \mathbf{( 9 5 \% )}\end{array}$ \\
\hline Needs for professional training & $0.54(0.40-0.66)$ \\
Seriousness of Type 2 Diabetes Mellitus & $0.67(0.56-0.76)$ \\
Importance of strict glucose control & $0.58(0.45-0.69)$ \\
Psychosocial impact of diabetes & $0.68(0.57-0.76)$ \\
Importance of autonomy & $0.67(0.56-0.76)$ \\
General scale & $0.65(0.54-0.75)$ \\
\hline
\end{tabular}

\section{Discussion}

Opting to culturally adapt an instrument is due to the various advantages already mentioned by the literature, such as savings time and the possibility of comparing the results with studies carried out in other countries ${ }^{(13)}$.

The studies that translated and adapted the DAS3 used methodology similar to that presented in this study, differing only in the composition of the specialists that composed the Committee of Judges. Despite methodological differences related to the performance of the Committee of Judges, the DAS-3 has proved to be a valid, reliable, and easy to understand instrument, for use by professionals in different countries ${ }^{(9,11-12)}$.

The main changes in the items of the translated version were related to the change of terms used to describe people who have diabetes and the reduction of the response options. The term "diabetic" is no longer 
used, due to the current principles that consider the importance of the autonomy of people living with the condition of diabetes in the process of choices in their care plan. The term "diabetic", used as a noun, labels people who have diabetes from a negative perspective and also implies that all people living with this condition are equal, resulting in the establishment of standardized behaviors that do not consider the life story and the individual needs of these people ${ }^{(17)}$.

The reduction of the response options should also be highlighted, which was considered relevant by the majority of the specialists. The justifications of the judges for the reduction of response options were related to the discussions presented in the international literature, which demonstrate the existence of differences in response patterns for Likert type scales among people with different education and cultures ${ }^{(18)}$.

The results of the evaluation of the psychometric properties indicated adequate internal consistency. Other studies found the presence of variation in the alpha values, which is justified by the instrument being applied in populations with different characteristics. Nevertheless, the versions translated and validated in other countries have also obtained internal consistency considered adequate ${ }^{(9,11-12)}$.

The median score of the retest can be considered equal to the median score of the test for the majority of the subscales. It should be noted that the differences in medians found for the overall score and the "psychosocial impact of diabetes" subscale, although significant, can be considered small ( 0.04 and 0.14 points respectively). The scores for each subscale were found to be similar to the results of a study conducted in Spain ${ }^{(11)}$.

A moderate to high discrimination capability was observed for the items, verified by the Polychoric Correlation Coefficients ranging from 0.443 to 0.813 . It was not possible to compare these coefficients with studies performed in other countries, since these studies did not use the Polychoric Correlation Coefficient.

In the analysis of the reliability through the stability, an ICC of 0.65 was obtained for the entire scale, demonstrating the temporal stability of the instrument ${ }^{(11)}$.

It is worth considering that evidence of validity should be accumulated to strengthen confidence in the use of scales. Therefore, it is suggested that this scale be applied with representative and more heterogeneous samples of health professionals, considering the different occupational categories and regions of the country.

\section{Conclusion}

It was concluded that the Brazilian version of Diabetes Attitudes Scale - third version, with the name Escala de Atitudes dos Profissionais em Relação ao Diabetes Mellitus (EAP-DM), fulfilled the criteria of equivalence between the original instrument and the translated version, demonstrating its validity and reliability for evaluating the attitudes of health professionals in relation to diabetes. The application of this instrument may help in the comprehension of care practices directed toward people who have diabetes and thus subsidize training programs that target health professionals.

\section{References}

1. Damasceno MMC, Zanetti ML, Carvalho EC, Teixeira CRS, Araújo MFM, Alencar AMPG. Therapeutic communication between health workers and patients concerning diabetes mellitus care. Rev. Latino-Am. Enfermagem. [Internet]. 2012 [Access 2016 Nov 26];20(4):685-92. doi: http://dx.doi.org/10.1590/ S0104-11692012000400008.

2. Stuckey $H L$, Vallis $M$, Kovacs $B K$, Mullan-Jensen $C B$, Reading JM, Kalra S, et al. "I do my best to listen to patients": qualitative insights into DAWN2 (diabetes psychosocial care from the perspective of health care professionals in the second diabetes attitudes, wishes and needs study). Clin Ther. [Internet]. 2015[Access 2016 Nov 26];37(9):1986-98. doi: http://dx.doi. org/10.1016/j.clinthera.2015.06.010.

3. Shortus T, Kemp Lynn, Mckenzie S, Harris M. Managing patient involvement: provider perspectives on diabetes decision-making. Health Expect. [Internet]. 2013[Access 2016 Nov 26];16(2):189-98. doi: http:// dx.doi.org/10.1111/j.1369-7625.2011.00700.x

4. Asimakopoulou K, Newton P, Scambler SS. Health care professionals' understanding and day-to-day practice of patient empowerment in diabetes: time to pause for thought? Diabetes Res Clin Pract. [Internet]. 2012[Access 2016 Nov 26];95(2):224-9. doi: http:// dx.doi.org/10.1016/j.diabres.2011.10.005.

5. Hernandez-Tejada MA, Campbell JA, Walker RJ, Smalls BL, Davis KS, Egede LE. Diabetes Empowerment, Medication Adherence and Self-Care Behaviors in Adults with Type 2 Diabetes. Diabetes Technol Ther. [Internet]. 2012[Access 2016 Nov 26];14(7):630-4. doi: http:// doi.org/10.1089/dia.2011.0287.

6. Knowles S, Lam LT, McInnes E, Elliott D, Hardy J, Middleton S. Knowledge, attitudes, beliefs and behaviour intentions for three bowel management practices in intensive care: effects of a targeted protocol implementation for nursing and medical staff. BMC Nurs. [Internet]. 2015[Access 2016 Nov 26];14:6. doi: http:// doi.org/10.1186/s12912-015-0056-z.

7. Spollen JJ, Thrush CR, Mui DV, Woods MB, Tariq SG, Hicks $E$. A randomized controlled trial of behavior change 
counseling education for medical students. Med Teachnol. [Internet]. 2010 [Access 2016 Nov 26];32(4):e170-7. doi: http://dx.doi.org/10.3109/01421590903514614

8. Papish A, Kassam A, Modgill G, Vaz G, Zanussi L, Patten $S$. Reducing the stigma of mental illness in undergraduate medical education: a randomized controlled trial. BMC Med Educ. [Internet]. 2013[Access 2016 Nov 26];13:141. doi: http://dx.doi.org/10.1186/1472-692013-141

9. Anderson RM, Fitzgerald JT, Funnell MM, Gruppen LD. The Third version of the Diabetes Attitude Scale. Diabetes Care. [Internet]. 1998 [Access 2016 Nov 26];21:14037. doi: http://dx.doi.org/10.2337/diacare.21.9.1403. 10. Hayes RP, Fitzgerald JT, Jacober SJ. Primary care physicianbeliefsaboutinsulin initiation in patients withtype 2 diabetes. Int ] Clin Pract. [Internet] 2008[Access 2016 Nov 26];62(2):860-8. doi: http://dx.doi.org/10.1111/ j.1742-1241.2008.01742.x

11. Hernández-Anguera JM, Basora J, Ansa X, Piñol JL, Martin F, Figuerola YD. La importância de la adaptación transcultural y la validación de la DAS-3 (Diabetes Attitude Scale) a la lengua vernácula (DAS-3cat): la versión catalana de um instrumento de medición de actitudes y motivaciones em la diabetes mellitus. Endocrinol Nutr. [Internet]. 2004 [Acceso 26 nov 2016];51(10):542-8. doi: http://dx.doi.org/10.1016/ S1575-0922(04)74663-X.

12. Babelgaith SD, Alfadly S, Baidi M. Assessment of the attitude of health care professionals towards diabetes care in Mukalla, Yemen. Int J Med Sci Public Health. [Internet]. 2013[Access 2016 Nov 26];2(4):159-64. doi: http://dx.doi.org/10.11591/ijphs.v2i4.3842.

13. Epstein J, Osborned RH, Elsworthd GR, Beatone $D E$, Guillemin F. Cross-cultural adaptation of the Health Education Impact Questionnaire: experimental study showed expert committee, not back-translation, added value. J Clin Epidemiol. [Internet]. 2015[Access 2016 Nov 26];68(4):360-9. doi: http://dx.doi.org/10.1016/j. jclinepi.2013.07.013.
14. Dias FSB, Marba STM. The evaluation of prolonged pain in the newborn: adaptation of the EDIN scale for the Brazilian. Text Context Nursing [Internet]. 2014[Access 2016 Nov 26];23(4):964-970. http:// dx.doi.org/10.1590/0104-07072014002100013.

15. Tavakol M, Dennick R. Making sense of Cronbach's alpha. Int J Med Educ. [Internet]. 2011[Access 2016 Nov 26];2:53-5. doi: http://dx.doi.org/10.5116/ijme. $4 \mathrm{dfb} .8 \mathrm{dfd}$.

16. Rodrigues MTP, Moreira TMM, Vasconcelos AM, Andrade DF, Silva DB, Barbetta PA. Instrumento mensurador de adesão para hipertensos: contribuição da teoria de resposta ao item. Rev Saúde Pública. [Internet]. 2013 [Acesso 26 nov 2016];47(3):523-30. doi: http:// dx.doi.org/10.1590/S0034-8910.2013047004439.

17. Peters KR. "Diabetic" and "Noncompliant Diabetic": terms that need to disappear. Clin Diabetes. [Internet]. 2012[Access 2016 Nov 26];30(3):89-91. doi: http:// dx.doi.org/10.2337/diaclin.30.3.89

18. Mottus R, Allik J, Realo A, Rossier J, Zecca G, Ahkion J, et al. The effect of response style on self-reported conscientiousness across 20 countries [Internet]. 2012 [Access 2016 Nov 26];38(11):1423-36. doi: http:// dx.doi.org/10.1177/0146167212451275
Corresponding Author:

Heloísa de Carvalho Torres

Universidade Federal de Minas Gerais. Escola de Enfermagem

Av. Alfredo Balena, 190

Bairro: Santa Efigênia

CEP: 31130-100, Belo Horizonte, MG, Brasil

E-mail: heloisa.ufmg@gmail.com
Copyright $\odot 2017$ Revista Latino-Americana de Enfermagem This is an Open Access article distributed under the terms of the Creative Commons (CC BY).

This license lets others distribute, remix, tweak, and build upon your work, even commercially, as long as they credit you for the original creation. This is the most accommodating of licenses offered. Recommended for maximum dissemination and use of licensed materials. 